\title{
Heritage for Sale! The Role of Museums in Promoting Metal Detecting and Looting in Romania
}

\author{
Iulian Ganciu 1,2 \\ 1 Institute for conservation and restoration, University of Applied Arts Vienna, Oskar Kokoschka-Platz 2, \\ 1010 Vienna, Austria; iulian.ganciu@oeai.at \\ 2 Austrian Archaeological Institute, Franz-Klein-Gasse 1, 1190 Vienna, Austria
}

Received: 3 October 2018; Accepted: 4 December 2018; Published: 6 December 2018

\begin{abstract}
The phenomenon of metal detecting in Romania is growing rapidly, with more and more cases being registered every year. In a context where there is less money for archaeological research, museums are relying more and more on discoveries made by metal detectorists in order to enrich their collections. This situation encourages the practice, and in time could have damaging effects on the archaeological heritage of Romania. Metal detecting represents an activity that has raised lots of debate, but the authorities have not yet taken action. Thus, this study is necessary: in order to find a middle ground between metal detectorists, archaeology, and the institutions responsible for the protection of heritage. Such a middle ground could be a bridge that leads to the better preservation of archaeological heritage in Romania. This study focuses on creating a policy to protect the archaeological sites of Romania, creating awareness among local communities as well as a policy that could be applicable elsewhere in other places that are also involved in this sort of activity.
\end{abstract}

Keywords: archaeology; heritage; looting; protection of archaeological heritage; metal detecting; museums

\section{Introduction}

Looting refers to the act of digging up artifacts without the recording of the excavation, context, or other activities related to its archaeological excavation, either for the purpose of collecting or sale [1] (p. 319). An illicit excavation refers to the undocumented, illicitly obtained artifacts that are excavated from the ground and sold for profit [2] (p. 111). This activity is a widespread action that affects all of the countries in the world in one way or another. Looting is the third largest illegal market after drugs and weapons [3] (p. 56); it funds international terrorism, denies human rights to culture, history, and identity, and depletes an irreplaceable resource.

This paper presents the current situation of protecting archaeological heritage from looting in Romania and the role of museums in promoting such activities. This paper looks into the legal framework and institutions that are supposed to protect archaeological heritage, and why their actions have been proven to be inefficient. In addition, this paper studies the extent to which the attitude of museums toward such practices are hindering the protection of archaeological sites. This project is an important one, because looting is an international problem, and although every country has different approaches and legislation, the patterns are similar. The aim of the paper is to find solutions for the case of Romania, and if viable, it could be applied widely.

The paper tackles issues regarding the protection of archaeological heritage from different perspectives. A critical discourse analysis of legislation and ethical guidelines has been done to observe loopholes and reasons why their implementation has failed. Interviews and questionnaires have been conducted with all of the stakeholders involved (where possible) in order to determine their position toward archaeological heritage and its protection and valorization. 


\section{Background}

Despite several international charters/conventions and agreements that were adopted to fight the illicit import or export of antiquities, this problem has never ceased to exist. Conventions such as the 1970 UNESCO (The United Nations Educational, Scientific and Cultural Organization) Convention on the Means of Prohibiting and Preventing the Illicit Import, Export, and Transfer of Ownership of Cultural Property or the 1995 UNIDROIT(The International Institute for the Unification of Private Law) Convention on Stolen or Illegally Exported Cultural Objects [4], as well as the ICOM (International Council of Museums) Code of Ethics for Museums 1986 [5] are meant to facilitate the protection of antiquities from looting and illegal trade. However, the conventions and other treaties deal only with the import or export of antiquities. How can looting be stopped if the trade of antiquities happens only within the confines of a country? This kind of practice is popular all around the world, and Romania is not an exception. However, Romania does, represent a particular case where looting has turned into a hobby that is seen as having the potential to create income for metal detectorists. Some of the reasons for this development reflect the economic situation of the country. Romania is a country in economic transition and has many problems, including, for example, a high unemployment rate [6]. Starting with the financial crisis that hit most of the world, including Romania, in 2008, the state budget for archaeological research has rapidly decreased. This has led to the closing of some excavations.

Regarding the legal aspect, the legislation concerning heritage protection in Romania is relatively new. Laws concerning the heritage protection were enacted in 2000, when the government voted Ordonanta 43 [7], on 30 January (Law Number 422 2001). This law still has a lot of imperfections, and has not been well implemented so far. According to this law (Article 49), the persons who discover artifacts by chance, through works of any nature conducted on public properties (described in the Article 46), are obliged to give them to the mayor or authorized personnel of the county within $72 \mathrm{~h}$. The fourth paragraph of the same article (49) states that the person who has made the discovery will be rewarded with $30 \%$ of the value of the discovery. If the discovery is an extraordinary one, an extra $15 \%$ of the value is added to the reward. The rest of the law is quite ambiguous, and the "limits" imposed by the law for protecting archaeological heritage is often easy to bend or interpret in the finder's favor.

The law fails to address a very important issue that is debated by all the archaeologists who are against metal detecting: is the discovery of an artifact by using metal detectors actually a discovery made by chance, or is a deliberate action? The law refers to 'works of any kind' without any other specification, which represents the weak link in the applicability of this law.

Regarding the owning of a metal detector, Romania has a law [8] that was enacted in 2004 (Monitorul oficial al Romaniei nr.704, 4 August 2004). The law states that any person can own a metal detector, but the owner is not allowed to use it on an archaeological site.

Another major problem is that areas that have archaeological potential, as well as already identified and well-known sites, are poorly protected; in most of the cases, there is no protection at all.

The media is also contributing to the popularization of this activity. I have identified 66 articles in national newspapers about major discoveries made by metal detecting since 2013. The majority of these articles contain keywords including "treasure", "Indiana Jones", "huge value", and monetary rewards from the state. All of the articles portray the people who have made these discoveries as heroes of national heritage. No other references are made to the actual practice, the reason why this practice is considered as being damaging for retrieving proper information, or why that information is important.

Another side effect that has been created-not only by the economic situation of the country, but also by the way that the archaeologists are dealing with local communities and the public-consists of the existing gap between archaeology as a science and the population, which is a gap that has been created only in the recent past. This gap has led to a lack of interest in archaeology from a major part of the population to such a degree that people do not know what the role of archaeology is, considering it useless. To narrow this down to local communities that live in the vicinity of archaeological sites, the situation is even more worrying. People who live next to an archaeological site do not know a 
lot about what is there, what is going on with any of the archaeological digs at such sites, or why they are undertaken. This situation is quite frequent, but there are also some exceptions, where local communities have been involved in the archaeological work and community engagement activities. In those situations, positive results can be seen, such as creating an attachment between the community and the archaeological sites, which in time could lead to them taking the side of archaeology, acting as "watchdogs" for the site.

\section{Government's View toward Cultural Property}

The government owns all of the cultural property in Romania, including archaeological heritage (Law 182/2000 art.5) [9]. Through the Ministry of Culture and its affiliated institutions, the state commits to protect, promote, and valorize the cultural heritage of the country. It is the main stakeholder, since it has the power to make decisions, create legislation, finance archaeological research, and approve the acquisition budgets of museums. In special cases, when the objects that a museum has to acquire exceed its acquisition budget, the Ministry can support the costs of the acquisition. Similar roles are attributed to local institutions, with the remark that they do not play any role in lawmaking, but they have a role in protecting and valorizing it.

The institutions affiliated with the Ministry of Culture have different obligations and purposes. The National Committee for Archaeology is a committee formed by experts in the domain who have an advisory role and set the standards in archaeology. This being said, it does not have a lot of power of decision-making, or legislative power. It has a fixed number of members, and their position is not influenced by political or economic instability (Enactment number 43 from 30 January 2000, Article 14.1-4) [7].

The National Institute for Heritage has some juridical power, managing funds for research, but also proposing projects to the Ministry. It has been affected by the economic crisis, which led to a dire shortage of personnel. The economic situation has slowed down the process of registration of archaeological sites in the Database of the National Archaeological Repertoire. The registration of possible sites in the database plays a very important role in protecting archaeological heritage from looting by limiting access to protected areas through the creation of boundaries (Governmental Decision number 593/2011, art. 1-2).

\section{Museums and Acquisition Policies}

Museums, although subordinated to the Ministry of Culture, have their own organization. They also manage their own budgets and respect ethical guidelines, which are all approved by the Minister of Culture (Law number 311/2003, art.2). Besides their educational purpose, museums also play a role in the protection of cultural heritage. This aim has been used as an argument for their acquisition policy, arguing that it is better to acquire the objects found by metal detectorists, disregarding the ways in which those objects were obtained, in order to ensure that the objects will remain in the country and can be presented to the public, rather than losing them to foreign collections.

Although the National Museum of Romanian History is a member of ICOM, some of the recommendations of ICOM's Code of Ethics are not found in its guidelines. More specifically, there is a lack of an acquisitions policy for objects or collections. In the principle of chapter two of ICOM's Code of Ethics, it is clearly stipulated that "museums have the duty to acquire, preserve and promote their collections as a contribution to the safeguarding of the natural, cultural and scientific heritage" [5] (p. 8). One of the recommendations of ICOM is that each museum should adopt and publish their policy that addresses the acquisitions of collections [5] (p. 8). The code of ethics stresses that no object or specimen should be acquired by any means if it does not possess a valid title [5] (p. 8). Those details 
are completely omitted in the guidelines of the National Museum of History of Romania ${ }^{1}$ [10], which is the biggest museum in Romania that deals with archaeology.

Behind this approach, there could also be another way of reasoning: museums acquire the objects for far less than their market price. It is their experts who decide the value of the objects, and they will pay only $35 \%$ of the value of the objects, or, in exceptional cases, $45 \%$. Yet, acquiring looted objects is not always seen as an act of preservation of archaeological objects, because encouraging this practice through demand can be also seen as a way of depriving the society of the information that the objects held when still buried in their archaeological contexts.

The actions of the museums have been blamed by archaeologists for encouraging people to continue with metal detecting by creating demand. Another observation worth mentioning is the lack of a clear policy related to museum acquisitions. The lack of any requirement for an ethical acquisition is the source for the legitimization of illicit traffic of antiquities and the looting of archaeological sites [11] (p. 248).

\section{Current Situation of Archaeological Research and Protection in Romania}

Archaeological research in Romania has also been affected by the financial crisis. The budget offered by the Ministry of Culture for the archaeological institutes and other responsible institutions has decreased considerably in the past five years. For example, in the year 2011, the Ministry of Culture offered 223,833 euros (1,000,000 Lei) for archaeological research and the restoration of historical monuments [12]. The funding had to be shared between archaeological sites as proposed and approved by the National Committee for Archaeology. In 2011, the money was shared as follows: 25,740 euros (115,000 Lei) for the archaeological site Histria, 11,400 euros (55,000 Lei) for the archaeological site Sarmisegetuza Regia (a UNESCO World Heritage monument), and 11,200 euro (50,000 Lei) for the archaeological site Ulpia Traiana. The rest of the archaeological sites that were financed by the Ministry of Culture received a fee that varied from 1200 euros to 2400 euros (5000-10,000 Lei), according to a Romanian newspaper [13]. Compared with the 2011 budget, the budget in 2014 was almost halved, to 134,300 euros (600,000 Lei). According to another newspaper, 2014 not only brought less finance for the archaeological sites, the number of archaeological sites that benefited from these finances also decreased [14]. According to an official bulletin from the Ministry of Culture offered in the Replica newspaper, after July 2014, the Ministry of Culture was determined not to offer any financial support for archaeological research [14].

Although the state has slowly decreased the direct financing of archaeological research, museums and universities still invest in archaeology from their own budgets, but most of their excavations are focused on important sites, such as Tropeum Traiani, Sarmizegetusa Ulpia, or Histria. A large number of sites, under the supervision of the Institutes of Archaeology from Romania (Bucharest, Iasi, and Cluj), were dependent solely on government financial support, which has hindered the research and other investments at the sites.

Analyzing the distribution of money for archaeological research indicates that the financial support coming from the government as well as from other sources is focused on a small number of sites. This consequently leaves other sites without any funding. Those funds are used by the archaeological teams for employing people-usually from local communities situated in the vicinity of the site-as well as for the acquisition of tools or materials required for restoration, conservation, or preservation.

A report of monitoring of the Dacian fortresses from the Orastie Mountains done in 2009 by the National Institute of Heritage by the archaeologist Daniela Mihai, who was responsible for monitoring the archaeological sites, and presented the precarious situation of many of the archaeological sites in

1 National Museum of History of Romania Guidelines, https://mnir.ro/wp-content/uploads/PDF/OMC_nr_2617_12.09. 2014_ROF_MNIR.pdf, accessed on 4 November 2018. 
Romania. The archaeological area has been on the UNESCO World Heritage List since 2009. The report describes the situation of all of the archaeological sites that are situated in the archaeological park. The first situation described in the report was the case of the most important fortress of them all: Sarmizegetusa Regia, the former capital of the Dacian Kingdom. The report shows that a single person maintains of the fortress: an employee of the Museum of Roman and Dacian Civilization. The fortress is not guarded or monitored. There is no entrance fee, no guides, and no other explanations, although the fortress has approximately 10,000 visitors annually, according to an unofficial statistic [15]. The fortress of Costesti-Blidaru is in a worse situation. The area is undeveloped, there is no maintenance of the site, and it is not guarded. The fortress of Costesti-Cetatuie is in a similar situation; the only guard that was working on the site had retired by the time the report had been completed. The fortress of Banitais is almost inaccessible, and no research or conservation has been done on it in the past decade. The situation of the fortification of Capalna is a particular one, because the site is not administrated by any institution or authority, and as a result, funds cannot be accessed [15]. From an administrative point of view, the archaeological park belongs to the Natural Park Cioclovina-Gradistea Muncelului, which has no direct administrator for the archaeological site in the park. This is why the sites cannot be guarded or maintained constantly, and it is also why the sites cannot apply for funds other than the ones received from the government. The National Institute for Heritage has requested a Governmental Decision through which the archaeological area's administration should be offered to the Council of Hunedoara County. The lack of protection and surveillance represents a factor of high risk for the conservation of the sites in the park, especially when it is recalled that they comprise some of the most important archaeological heritage in Romania and also a World Heritage Monument. At the same time, the archaeological area of the Dacian fortresses represents the area from which 24 golden Dacian bracelets were looted between 1998-2001 and exported. Of those 24 bracelets, the Romanian state managed to recover only 13 between 2007-2015.

Another report concerning the state of the Dacian fortresses in the Orastie Mountains was done in 2016 [16], and no improvement has been signaled.

Similar to the Dacian fortresses, many other archaeological sites in Romania are not protected or subject to professional investigation, which makes them defenseless against possible looters.

\section{Metal Detectorists and their Relationship with Museums}

Since 2012, metal-detecting activity has become more and more popular in Romania, to the point where there are well-organized non-governmental organizations (NGOs) of metal detectorists with their own databases, besides the 'practitioners' of this hobby.

According to one of the databases used by the Romanian metal detectorists, they have delivered 430 discoveries (Table 1 ) to the Romanian museums in less than two years (the NGO called "Pro-detectie" was created in the spring of 2014) [17]:

Table 1. List of museums and the numbers of objects acquired from Pro-detectie.

\begin{tabular}{cc}
\hline Institution & Number of Objects Acquired from Pro-detectie \\
\hline Muzeul National de Istorie a Romaniei & 199 \\
Muzeul Judetean Mures & 77 \\
Muzeul de Istorie Nationala si Arheologie Constanta & 67 \\
Muzeul Judetean de Istorie Brasov & 38 \\
IGSU-IGPR & 20 \\
Muzeul de Arheologie Callatis Mangalia & 14 \\
Muzeul Judetean de Istorie si Arheologie Prahova & 10 \\
Complexul Muzeal “Iulian Antonescu” Bacau & 8 \\
Muzeul de Istorie si Arheologie Piatra Neam & 6 \\
Directia Judeteana de Cultura din Iasi & 3 \\
Muzeul National de Istorie a Transilvaniei & 2 \\
\hline
\end{tabular}


Table 1. Cont.

\begin{tabular}{cc}
\hline Institution & Number of Objects Acquired from Pro-detectie \\
\hline Complexul National Muzeal “Curtea Domneasca” Targoviste & 2 \\
Muzeul National al Unirii Alba Iulia & 2 \\
Muzeul Regiunii Portilor de Fier & 1 \\
Muzeul Oleteniei & 1 \\
Muzeul Tarii Fagarasului & 1 \\
\hline
\end{tabular}

With the exception of the National Museum of History of Romania, which acts as a central structure for the museums and has a larger budget for acquisitions than the rest of the museums, the remaining objects were delivered to local museums. That the museums acquire all these objects from looters creates a precedent and encourages undesirable practices.

There are cases of successful collaboration between museums and metal detectorists in Romania, although such cases are still rare.

The collaboration between the National Museum of History and Archaeology Constanta (MINAC) and the metal detectorist group "Pro-Detectie", which was signed in 2014 [18], was valid for two years with the possibility of extension if none of the parties had objections (Article 2). In this collaboration, both parties agreed to respect all of the laws referring to the protection of national cultural heritage, as well as the laws of museums and collections, and the protection of archaeological sites and areas. Another purpose of the collaboration is the recovery of the archaeological context of discoveries made with the help of metal detectors, promoting the discoveries made by the users of metal detectors, and volunteering the collaboration of members of the association with archaeologists of MINAC (Article 1, Article 4). The Association Pro Detectie (APD) is obliged to maintain a constant communication with MINAC in order to inform MINAC about their actions on the territory of the county Constanta and vice versa, as well as promote MINAC's collections on their websites (Article 4).

MINAC commits itself to inform Pro Detectie about actions of common interest and about areas with archaeological potential in order to avoid infringement. It provides specialists every time APD informs them about a possible discovery in order to recover the archaeological context, offers a place in the museum to exhibit the discoveries made by APD, evaluates their finds within 30 days from the discovery, and offers them the rewards according to the legal provisions (Article 5).

Another example of a successful collaboration between museums and metal detectorists is represented by the case of the County Museum Alexandru Stefanescu from Targu-Jiu, where an exhibition of 300 archaeological objects discovered in 2015 with the help of metal detectors were used for an exhibition that opened its doors on 30 December 2015 [19]. From the 70 persons who have a metal detector registered in the county, only eight have brought objects to the museum. Others have not discovered anything, or see this activity as a treasure hunt [20]. The discoveries made by metal detectorists and exhibited in the museum are made of silver, bronze, or iron, some being classified as treasure. Some have led to archaeological investigations in the areas where they were found, contributing to the discovery of three archaeological sites [20]. This activity represents another step in the collaboration between museums and metal detectorists.

Although the contacts and collaboration between museums and metal-detector users have increased considerably in the past three years, most museums are still reticent to create educational workshops for them, train them to record information related to context and the area of discovery, or even collaborate with them. For example, the National Museum of Romanian History-the biggest beneficiary from metal detecting discoveries-has no collaboration project with metal detectorists. One of the reasons for a lack of collaboration with them is because the administration of the museum is split into two camps.

2 General Inspectorate for Emergeny Eituations (IGSU)-The General Inspectorate of Romanian Police(IGPR) 
The general director of the National Museum of Romanian History, Ernest Oberländer Târnoveanu, has declared in Gandul, a national newspaper, that the finder of the Golesti treasure is an example of morality and civic spirit, understanding that the treasure could be valorized only in an important institution [21]. Also in 2013, in a news report broadcast on the national television (TVR), he declared that archaeologists should learn from looters, accusing archaeologists of being secluded with outdated conceptions that will lead eventually to the loss of heritage, and they should learn from this lesson in order to be one step in front of the detectorists [22] $]^{3}$.

On the other hand, Paul Damian, the vice-director of same institution ${ }^{4}$ who supervises the archaeology departments, believes that metal-detecting activities have been intensified lately, and the National Museum of History of Romania has acquired and still acquires objects that come from metal detecting. He considers that the general director of the museum, Ernest Oberländer-Târnoveanu, sees the acquisition as a safeguard action, believing that if the objects are not acquired by a museum, they could end up on the illegal market and never seen again, or for which efforts for repatriation have to be made. Paul Damian believes that museums encourage this practice because they pay less for the objects ( $30 \%$ of the value of the object, occasionally $45 \%$ if the discovery is extraordinary). In this situation, the focus is on the artefact per se rather than on the information that the artifact carries, making the archaeology department a neglectable part of the museum.

The question that arises most often when talking about metal detecting and its risks is: why is the protection of the archaeological heritage of a country important? The cultural property represents one of the core elements of civilization and national culture, and its true value can be appreciated only if the maximum information regarding its origin, history, and original context can be retained [23] (p. 843). This means the recording of all the possible information in the moment of discovery it is required. At the same time, the acquisition of such objects contrasts with one of the main roles of museums, the educational mission, which is not fulfilled if they purchase artifacts that do not have complete information. On the other hand, the examples of collaborations between metal detectorists and museums prove that they could benefit both groups, preventing in this way the loss of information and the risk of damaging the objects that are found.

\section{Actions and Reactions of the Stakeholders Involved}

There were no public reactions from the national government regarding the issue of metal detectorists and their activities until the beginning of 2016. Before this date, the government's position concerning the increase of metal detecting was not clear at all. The former Minister of Culture, Vlad Alexandrescu, declared then that the Ministry is considering the possibility of making metal detecting illegal [24], but his promises never came through, and he resigned from the Ministry of Culture on 27 April 2016 [25]. This raises an important question. Why has the Ministry of Culture not acted yet concerning the issue of metal detecting? The situation can be explained by the instability at the level of the Ministry of Culture, which from 2012 until 2018 had 13 ministers. The longest period spent by a minister in his office was one year, Daniel Constantin Barbu, in the period 21 December 2012 to 17 December 2013 [26]. This instability has led to a lack of clear policy concerning the protection of national heritage, as well as ministers not having enough time to create and implement long-term policies, while new ministers come with their own agenda.

Another action of the Romanian government that has led to a negative reaction from the archaeologists is represented by the public events of awarding metal detectorists, such as in the case of Iulian Enache. In September 2013, the Prime Minister of Romania, Victor Ponta, personally offered a reward and his appreciation to a metal detectorist, Iulian Enache, for making a very

3 TVR1, Telejurnal, 8 noiembrie 2013-declaration of the general director of MNIR, about the lessons that archaeologists could learn from looting, minute 21:50, http:/ / www.tvrplus.ro/ / editie-telejurnal-150122, accessed on 23rd of October 2018.

4 Interview with Paul Damian, 21 January 2017. 
important discovery: a hoard of $50 \mathrm{~kg}$ of Ottoman silver coins, which is also known as the Golesti treasure [27]. In reaction to the issue surrounding the use of metal detectors and awards offered by the government, archaeologists submitted a petition to the Ministry of Culture called National Heritage between Professionalism and Amateurism (Patrimoniul istoric national intre profesionism si amatorism) in February 2014. The petition was started by the archaeologists of the National Museum of History of Romania, denouncing its director-who was also the president of the National Committee of Museums and Collections (a committee that oversees over the acquisitions policies in order to avoid abuses or misconducts)—for his acquisition policy, claiming that the museum has spent 107,000 euros for such acquisitions, while investing only $10 \%$ of that sum in archaeological research $[28]^{5}$. The petition also highlights the necessity of a new legislation in which the term 'finding by chance' should be redefined.

The position of archaeologists toward metal detectorists is more radical; they would prefer this sort of practice to be declared illegal. Some are willing to collaborate with detectorists, but that opinion is not a general one. Their reluctance toward metal detecting lays in the numerous cases of metal detecting and illicit trafficking of antiquities that happened in the country, as the cases of the Dacian Gold Bracelets, when 21 solid gold bracelets were looted from the site of Sarmzegetuza Regia between 1999-2001 [29] ${ }^{6}$.

The opposing camp, metal detectorists, form a group that has constantly grown over the past five years, as the practice of metal detecting gains more and more popularity among the general public. Most detectorists see it as a way of expressing their passion for history and archaeology, although there are also people who do it for the money that comes with the rewards offered by the state. Nonetheless, there is emotional engagement with the artifacts that they discover that is connected with this passion for history, rootedness, connectedness, and identity [30] (p. 288). The detectorists' requests to make this hobby legal also face many obstacles from the authorities and academics. They have also ask for a change in legislation that is similar to the one used in the United Kingdom (with the exception of Scotland), where finders of archaeological objects become the owners of those items, and thus eligible for a reward that will consist of the whole value of the find [31] (p. 39). In Romania, the group is marginalized by archaeologists and some institutions, although they could play a role in the creation of knowledge and enriching national archaeological heritage.

Their imagination is also fueled by the media. The media presents the discoveries of the metal detectorists as extraordinary, giving them an aura of "Indiana Jones". Rewards are often mentioned, while no recommendation is given relating to the importance of archaeological context or the necessity for an archaeological research, nor any information related to the legislation that deals with such issues. In this context, the public could perceive these activities as legal, but without understanding the importance or methods of preserving archaeological heritage. Media can play an important role in promoting the image of archaeology from an educational perspective. With the media's help, the gap created between archaeology and the general public could be filled.

How are the local communities affected by the increase of metal detecting in the country? First and foremost, where the attachment to the site is present, local communities often perceive archaeological objects as gifts from ancestors passed down from generation to generation. Digging them out is seen as digging someone's grave or as destroying a place that is representative of local pride.

Local communities show attachment to the archaeological sites in two circumstances. The first regards whether the archaeological site was always part of their landscape, and if they see it as part of their daily life. Yet, in this situation, their care for the site is not manifested through actions, as in

5 https://www.petitieonline.com/patrimoniul_istoric_national_intre_profesionism_si_amatorism, accessed on 22 October 2018.

6 https://traffickingculture.org/encyclopedia/case-studies/dacian-gold-bracelets/, accessed on 25 October 2018. A similar case is that of the two bronze tablets representing Roman tabulae, which contain the laws of the old town Troesmis. These were stolen from the archaeological site of the locality in 2002, and subsequently recovered by Romanian authorities in London, where they had been put up for auction. 
preventing damage. Also, they are attached to an archaeological site if they gain financial benefit from it through tourism or work on excavations, which in the end lead to the creation of a stronger connection with the site and the perception of it as a resource that needs to be carefully exploited under the supervision of experts, such as archaeologists.

Secondly, the lack of attachment toward archaeological sites from the local communities situated in their vicinity can be explained by their lack of engagement with the landscape. However, this behavior can also be explained by the lack of interest, in terms of community engagement plans, of the archaeologists and local (or national) authorities who are responsible for that. In most of these cases, locals were not aware of the historical value of the sites in the area, and in some cases, they were not aware of their existence.

\section{Legislation Concerning the Protection of Archaeological Heritage in Romania, Italy, and the United Kingdom (UK)_A Parallel}

A comparison of similar legislative efforts in other countries is necessary, because it corresponds with the requests of the two conflicting stakeholders: archaeologists (demanding a strict legislation, such as the Italian one) and detectorists (who desire a legislation that is more permissive and provide rewards that are equivalent with the value of the finds, similar to the one in the UK). This analysis is meant to provide insights into the applicability of that particular legislation to the Romanian case. At the same time, through this comparison, I am looking for solutions that can be found in other international legislation. What aspects of the legislation that are mentioned can contribute to an improvement of the Romanian issue concerning metal detectorists and the protection of archaeological heritage?

Romanian legislation concerning cultural property barely mentions the public. Cultural heritage is seen from a top-down perspective: the state aims to have complete control over its cultural property, but a plan for the enhancement of that cultural property is lacking. The laws have not been completely implemented, owing to a lack of funds to support local and national authorities in the process of implementation. As well as this, the laws are easy to interpret differently from the original intention, which can offer loopholes in the law that may encourage illicit trading. As mentioned before, the issue lays in the lack of a definition for a "discovery made by chance" through "works of any nature".

The Italian Government owns all of the antiquities, whether they are known or unknown [32] (p. 244). Under a law that has been enforced since 1909, all of the antiquities found on Italian territory are considered to be the property of the state, which is responsible to hold it in trust for its people [33] (p. 11). Nowadays, the main regulations concerning the protection of cultural property are represented by the Legislative Decree No. 43 of 22 January 2004, which is also known as the Landscape and Cultural Heritage Code [34]. The strict ownership law is supported by good export control regulation. The control over exports and the protection of cultural property is provided by a special art squad from the Carabinieri, the Italian police, the Comando Carabinieri Tutela del Patrimonio Culturale - TPC (The Carabinieri Command for the Protection of Cultural Property), and the Ministry of Finance's police force, Guardia di Finanza [35] (p. 939).

The Carabinieri start from the premise that it is easier to protect cultural property than it is to recover stolen and looted objects, and has therefore invested a lot in education, outreach, and security efforts [33] (p. 37). Through their educational and outreach program, they aim to highlight for the public the importance of heritage in situ and why archaeological sites should be protected from looting, considering that an informed public will be less tempted to purchase looted antiquities [33] (pp. 37-59). At the same time, they provide an educational game that is aimed at 6-12 years-olds and can be downloaded for free from their website; within this game, the children learn about the main issues 
related to the protection of cultural heritage, discover the value of it, and are educated as to the importance of its preservation $[36]^{7}$.

Italian legislation provides not only the financial support for the fight against illicit trade, but also the human resources necessary for better control. In its legislation concerning cultural property, Italy sees the public as the main consumer of its heritage, and the state protects its heritage for the people ([33] p. 11). The state is responsible for enhancing the cultural heritage in order to promote knowledge of the cultural heritage and ensure the best conditions for the utilization and public enjoyment of that heritage, as well as the promotion and support of conservation [34] (Decree No. 43 of 22 January 2004, Art.6.1). In its mission to protect national cultural property, Italy appeals also to means other than law enforcement. One of those means is education, which is seen as a long-term solution that will lead to the better protection of cultural property by making its citizens aware of its importance.

British $^{8}$ legislation differs again. At its core lies the concept of 'treasure', which is a term that is very clearly explained in the Treasure Act (Section C Article I.6, Article I.7) [31]. Britain sees in the discoveries made by the public a real boost in knowledge about national heritage, which it supports with the rewards offered for the finders, namely the whole value of the artifacts discovered. A difference worth mentioning is that the landowners, on whose property the discoveries are made, are eligible for a share of the reward. They are the rightful owners of the objects, which represents a bottom-up perspective of ownership that is different from the cases of Italy or Romania.

In Britain, that the finders receive the whole value of the object, and are also eligible for a reward even if they call archaeologists to finish the job, encourages recording data about the finds, as well as discouraging bad behavior [31] (p. 39). Italy and Romania offer just a part of the value of the find as a reward, which might encourage the finders to dig the objects themselves, fearing that in a different case, there will be no reward, since that is not mentioned in their legislation ${ }^{9}$. Another unfortunate outcome could be the selling of the artifacts to others in order to obtain a greater financial gain. The difference between Italy and Romania in that this situation is represented by the level of law enforcement and the resources that are allocated to fight the illicit trade, which is far more successful in the case of Italy ${ }^{10}$.

The database that is available for the public in Britain represents another useful instrument that not only keeps track of the discoveries, but can also be used in a scientific way, enriching knowledge about landscape biographies [37] The existence of the Portable Antiquities Scheme (PAS) database [37], together with a clear definition of what is seen as a treasure, makes the use of metal detecting in the search for archaeological finds not only accepted, but also legal under the prescribed conditions. In Italy and Romania, this would be illegal. Yet, the practice of Romanian museums to acquire objects that were found by metal detectorists with the help of a metal detector without any opposing reactions from the authorities positions Romanian practice between the Italian practice and the British situation. The problem here lies in the Romanian legislation having loopholes that could be interpreted in the advantage of metal detectorists. Also, Romania does not dispose of the funds to set a database (similar to the one in the United Kingdom) or a very specialized task force to fight against the illicit trafficking of antiquities (as in the case of Italy). In conclusion, the Italian legislation is the one that presents a viable solution for the case of Romania, as the changes required in the legislation would not be very radical; only small updates are required. The educational approach proposed by the Italian legislation and its task forces aims at increasing public awareness concerning the protection and valorization of

\footnotetext{
Carabinieri Video Game, http:/ / www.carabinieri.it/cittadino/giochi/missione-tpc, accessed on 25 October 2018. Refers strictly to the cases of England and Wales.

9 Landscape and Cultural Heritage Code, Decree No. 43 of 22 January 2004, Article 92 in the case of Italy. Ordonanta numarul 43 privid protecia patrimoniuli arheologic si declararea unor situri arheologice ca zone de interes national. Bucuresti, 30 January.2000 in the case of Romania.

10 The control over the export and protection of cultural property is provided by a special art squad from the Carabinieri, the Italian police, the Comando Carabinieri Tutela del Patrimonio Culturale-TPC (the Carabinieri Command for the Protection of Cultural Property), and the Ministry of Finance's police force, Guardia di Finanza.
} 
cultural heritage; this is an initiative that Romania has not made use of so far $[38]^{11}$, but from which it could definitely benefit.

\section{Solutions}

All countries protect their archaeological heritage through laws, both domestic and international, but this is a top-down approach to prevent the destruction of sites. International laws reflect mostly on the state and its institutions, while state laws apply to individuals; however, in most of the cases, the sanctions are not drastic, which means that the risk of sanctions could be far less than the benefits [39] (p. 210). If the law is not well enforced, the looting of archaeological sites and trafficking of cultural heritage may develop. In the case of Romania, museums play an important role in promoting looting by maintaining a demand for such artifacts.

A radical legislative change is not necessary; the law does not need to consider prohibiting metal detecting or guaranteeing full ownership rights for the finders of objects. Both proposals could easily backfire. The first could encourage illegal activity that could lead to the loss of heritage to foreign collections, while the second-in the actual context, where there is a lack of archaeological education and broad responsibility for cultural heritage-could transform this activity into a real treasure hunt. However, a legislative change is necessary in order to deal with current issues that were not foreseen in the early 2000s when the legislation for protecting the archaeological heritage was enacted. These changes should clarify the definition of a discovery made by chance, and under what circumstances such a discovery should occur.

On the other hand, laws play an important role, but they also have a lot of limitations. The legislation does help protect archaeological heritage from illicit threats, even the countries that are best-prepared countries to fight illicit trade, such as Italy, have only a 10\% recovery rate [40] (p. 239). When gaps in the law are easily exploited, social norms can play an important role in regulating behavior, and thus should be rooted in a good education system. Public education is a recurrent topic in archaeological heritage management, as one of the main solutions to indifference and the damaging of archaeological sites; education is intended in order to increase public knowledge of the past and why its protection is important [41]. Education can represent the means of bringing archaeology closer to the public, thus filling the gap between academia and its consumer.

A good model of an educational program against looting has been presented by Hicks, and although it was tested in the United States, it could have wider applicability. Starting from the assumption that archaeology has a huge avocational and hobby audience, the education of the wider public should be useful in approaching the issue of looting [42] (p. 140).

The purpose of the proposed educational system is to encourage the public to understand the connection between science and the role that artifacts play in research. It does this by explaining what information can be extracted from an object, as well as the importance of the context in which the object was set [42] (p. 140). The education has to be layered, having different target groups that focus on youth education, adult learning, and the groups that are very interested in archaeology, such as metal detectorists and amateur archaeologists. In all of the programs, archaeologists, museums, and law enforcement representatives have to be involved directly or indirectly through the creation of information materials, such as booklets or brochures.

Educational programs for children and youth must mention not only the importance of stewardship but also looting and trafficking, using discussions, the hands-on experience of archaeological objects, simulations of archaeological excavations, or role-play to stimulate multiple viewpoints [42] (p. 141). This way, young people learn to report anything they discover, as well as

11 Bors argues that although Article 9 of law 43/2000 suggests that every institution that is responsible for the protection and valorization of archaeological heritage has to develop educational activities to increase public awareness, those activities are extremely rare. 
understand the importance of archaeological objects, stressing the scientific value over the financial value of the object for the wider understanding of our past. Through education for this age category, changes will come with the change of demographics.

As to what concerns the citizens, role play can reveal the complexity of the issue, and can clarify the importance of context and what can add to the scientific value of the object. This must be backed by law enforcement training, where violations of legislation and their outcomes are explained, as well as by lectures from archaeologists, published materials, and videos. These programs must be free of charge, informing local communities around the sites and making use of the media to reach to the wider public.

Another good model of the role of archaeology in education is represented by the Portable Antiquities Scheme educational projects, where courses have been offered for amateur archaeologists, but also published in the form of fliers and distributed among the metal-detecting communities. Finders are encouraged to properly record the objects found and the find spots, as well as contact archaeologists and gain access to information [43] (p. 204). Archaeologists can provide them with education regarding methods of excavation and registration of context, as well as primary preservation for the objects that they have discovered, which sometimes are cleaned and damaged, to ensure that not all the information is lost. The main fear of archaeologists when it comes to educating a metal detectorist is that it could backfire by training professional looters who could take advantage of their newly gained skills for personal purposes.

Archaeology must represent a bridge that connects contemporary minds with individuals from the past [30] (p. 298). Archaeologists can represent a catalyst in their own processes of learning, through involvement in the education of metal detectorists, but also of the wider population.

From the perspective of Romanian archaeologists, the best way of protecting archaeological heritage from looting is to prohibit the use of metal detectors in Romania. The pressure that archaeologists have put on the government could actually lead to the prohibition of metal detecting, since the former Minister of Culture has declared that he is considering this possibility. However, is this a viable solution that will lead to the protection of archaeological heritage? Prohibition could, in fact, make things worse. Nowadays, there are bona fide metal detectorists who will report their finds. A law that makes metal detecting illegal could push them to break the law and sell the objects on to foreign collectors. In the current state, museums receive constant requests for the evaluation of objects (valuable or not valuable from the museum's perspective) that are found by metal detectorists, hoping they will be entitled to a financial reward. This does not exclude the possibility that valuable objects could be sold to foreign collections, but museums represent a safer, less risky way of obtaining an income from metal detecting.

At the same time, the case of the Italian art crime unit mentioned above represents one of the world's most successful policing efforts, but prosecution is an expensive exercise. Unfortunately, Romania is not yet ready to fund such an approach because of a lack of human and financial resources, which makes it difficult if not impossible to monitor every archaeological site. Archaeologists have to collaborate closely with law enforcement to guide and educate local officers in possible investigations, but also vice versa: archaeologists could be trained in collecting evidence for possible prosecutions [42] (p. 133).

Romanian museums must also include acquisition policies in their ethical guidelines, moving toward a cautious acquisition policy that discourages the intensification of metal detecting, enhances the transparency of museums activities to justify the expenditure of public money, supports collaborations with metal detectorists, and reinforces this through outreach and educational programs on the role of archaeology and the importance of its protection. In case their attitude does not change, shaming museums to force them to change their attitudes is a plan B solution, because shaming will affect their behavior when disapproval from the community impacts their freedom of action [39] (p. 216).

What can the metal detectorists bring to archaeology? The advantage is that they intimately know intimately the landscape, which is knowledge that comes from long experience and observation 
of the natural world [44] (p. 65). Collaboration with metal detectorists represents a solution to this problem, which will benefit both groups. Archaeologists could benefit from amateurs' knowledge of the landscape, their work as volunteers, and their technology. The collaboration helps build trust between the two parties, and perhaps in this way, the amateur archaeologists will call archaeologists in cases where they discover artifacts. Combined with education on the importance of context and means of registering different types of information, more complete information about the area and object will be generated. Therefore, detectorists and other amateurs will also become responsible. On the other hand, the amateur archaeologists will satisfy their passion for archaeology and history, and practice their hobby in a more responsible way.

Although not all metal-detector users have bad intentions, archaeologists and museums face a difficult situation, as it is very hard to distinguish between bona fide metal detectorists and those who are not so well intentioned, i.e., looters. The metal detectorists who are members of an association have more privileges, since the museums have started to collaborate with those associations. Being part of an association brings some transparency to their practices by keeping control of metal detectorists' activity, the types of metal detectors used, and the discoveries that are made, including providing a channel to the institutions to which they report their discoveries. At the same time, they have to adhere to a code of ethics and have meetings with the association where they report on their activity. All in all, an association has a normative role for a metal detectorist, conferring upon them greater credibility.

Metal detectorists have to be encouraged to collaborate with archaeologists and authorities, as well as record contextual information if there is no archaeologist available or reachable, and the exact location of the discovery recorded with a global positioning satellite (GPS).

Local communities have to be engaged more in archaeology and awareness and educational programs. This way, the importance of the sites situated nearby could be stressed, as well as the reason why their protection is important. Local people must also be consulted when possible about matters of planning and interpretation.

The media, on the other hand, must be approached to promote an image of archaeology that is closer to reality, rather than one that encourages treasure hunting. They can also contribute through educational programs or shows, since the mass media comprises a good platform for outreach programs.

A change of attitude is also needed from both archaeologists and metal detectorists. This can be achieved through collaboration and education.

At the end of a trial period, results must be analyzed, and according to the changes observed in the patterns of this practice and the evolution of the whole situation, proper evidence-based legislative changes should be taken.

\section{Conclusions}

The acquisition policies of museums, which has focused on objects found with the help of metal detecting, has created a demand for metal-detecting activities. This demand, alongside the legislative and logistic context, can have damaging effects on the archaeological heritage of Romania. It has to be stressed out that transparency is a requirement for museums and metal detector associations. This represents a step toward avoiding abuses of the loopholes that are present in the law.

Although two of the opposing parties, archaeologists and metal detectorists, have asked for changes in legislation (archaeologists request making metal detecting illegal or as strict as the Italian legislation, while metal detectorists desire a higher reward from the state, as in the case of UK), a radical change is not yet required; however, a legislation update is necessary. First and foremost, it has to be clarified what the discovery 'made by chance' means.

The educational approach proposed by the Italian legislation and its task forces that aims at increasing public awareness concerning the protection and valorization of cultural heritage is an initiative from which Romania will definitely benefit. This is a change that could be easily implemented. 
One of the most important steps toward the protection of archaeological heritage is made through education. The core of the issue lies in the gap between archaeology and the general public, which has not only affected the perception of archaeology at the national level, but also created a lack of knowledge regarding its importance. This has led to indifference toward the protection of archaeological heritage. Thus, education is necessary for all age categories, as well as for amateur archaeologists.

Collaboration between archaeologists and metal detectorists will increase knowledge concerning the Romanian archaeology. This collaboration has already proven to have fruitful results for both sides; one of these results is that museums are able to retain as much information as possible from the objects discovered by metal detectorists, while metal detector enthusiasts are able to freely enjoy their hobby.

At the same time, the state must invest in archaeological site registration and encourage training for adequate personnel to deal with issues of heritage, not only at a national level but also at a regional level.

To reach these solutions, all stakeholders must be open to constant negotiations.

Funding: This research received no external funding.

Conflicts of Interest: The author declares no conflict of interest.

\section{References}

1. Hart, S.M.; Chilton, E.S. Digging and destruction: Artifact collecting as social practice. Int. J. Herit. Stud. 2015, 21, 318-335. [CrossRef]

2. Proulx, B.B. Archaeological Site Looting in "Glocal" Perspective: Nature, Scope and Frequency. Am. J. Archaeol. 2013, 117, 111-125.

3. Szopa, S. Hoarding History: A Survey of Antiquity Looting and Black Market Trade. Univ. Miami Bus. Law Rev. 2004, 13, 55-89.

4. UNIDROIT. UNIDROIT Convention on Stolen or Illegally Exported Cultural Objects; UNIDROIT: Rome, Itatly, 1995.

5. International Council of Museums (ICOM). ICOM Code of Ethics for Museums; ICOM: Paris, France, 2013; ISBN 978-92-9012-407-8.

6. Diacon, P.E. The Economic Transition of Romania from a Behavioural Economics Perspective. CES Work. Pap. 2012, 4, 296-305.

7. Ordonanta Numarul 43 Privid Protecia Patrimoniuli Arheologic si Declararea Unor Situri Arheologice ca Zone de Interes National. Available online: https:/ / lege5.ro/Gratuit/gezdiobqgy / ordonanta-nr-43-2000privind-protectia-patrimoniului-arheologic-si-declararea-unor-situri-arheologice-ca-zone-de-interesnational (accessed on 15 October 2018).

8. Ministerul Culturii si Cultelor. Ordinul Nr. 251/409/2275/M 115 from 31 mai 2004; Ministerul Culturii si Cultelor: Targoviste, Romania, 2004.

9. Legea Nr.182/2000 Privind Protejarea Patrimoniului Cultural Bational Mobil, Republicata 2008. Available online: http:/ / www.dreptonline.ro/legislatie/lege_protejarea_patrimoniu_cultural_national_mobil_182_ 2000.php (accessed on 15 October 2018).

10. Guidelines and Regulations of the National Museum of Romanian History. Available online: https://mnir. ro/wp-content/uploads/PDF/OMC_nr_2617_12.09.2014_ROF_MNIR.pdf (accessed on 4 November 2018).

11. Renfrew, C. Museum Acquisitions: Responsibilities for the Illicit Trade in Antiquities. In Archaeology, Cultural Heritage and the Antiquities Trade; Brodie, N., Kersel, M., Luke, C., Tubb, K.W., Eds.; University Press of Florida: Gainesville, FL, USA, 2006; pp. 245-257. ISBN 9780813037110.

12. Histria, Pompeiul Românesc, Părăsit de Stat şi „„săpat” de Interese Obscure. Available online: http: / / archaeoheritage.ro/2012/07/histria-pompeiul-romanesc-parasit-de-stat-si-sapat-de-interese-obscure/ (accessed on 16 October 2018).

13. De ce Este Nevoie de un Sef al Directiei Patrimoniu Cultural? Available online: http://www. historia.ro/exclusiv_web/general/articol/ce-este-nevoie-un-ef-al-direc-iei-patrimoniu-cultural (accessed on 16 October 2018). 
14. Câţi Bani (n-)au Primit Cetăţile Dobrogene de la Ministerul Culturii. Available online: http://www. replicaonline.ro/cati-bani-n-au-primit-cetatile-dobrogene-de-la-ministerul-culturii-198631/ (accessed on 16 October 2018).

15. Raport de monitorizare a cetatilor dacice din muntii Orasitei. Available online: http://patrimoniu.gov. $\mathrm{ro} / \mathrm{ro} /$ monumente-istorice/lista-patrimoniului-mondial-unesco/9-monumente-istorice/34-raport-demonitorizare-a-cetatilor-dacice-din-muntii-orastiei (accessed on 17 October 2018).

16. Fundația Dacica. Evaluare a Raportarii Periodice Catre World Heritage Center (Periodic Reporting-Second Cycle) cu Privire la Cetatile Dacice din Muntii Orastiei; Fundația Dacica: Hunedoara, Romania, 2016.

17. Detectii. Available online: http://www.detectii.ro/categories/ (accessed on 26 October 2018).

18. Protocol de Colaborare din Data de 4 Iulie 2014. Available online: http://prodetectie.ro/doc/ protocolconstanta.pdf?8dacc2 (accessed on 28 October 2018).

19. Expoziție “Detectoare și Metale”. Available online: http://www.tvsud.ro/expozitie-detectoare-si-metale. html\#.VwutxbfhCUk (accessed on 25 October 2018).

20. Cine sunt „detectoriştii“ şi cum reuşesc să îmbogăţească Tezaurul României. Vestigiile descoperite de pasionaţii de istorie, expuse la Muzeul Judeţean Gorj. Available online: http:/ / adevarul.ro/locale/targu-jiu/cine-detectoristii-reuses-imbogateasca-tezaurul-romaniei-vestigiiledescoperite-pasionatii-istorie-expuse-muzeul-judetean-gorj-1_5683ff9e37115986c6f941d1/index.html (accessed on 27 October 2018).

21. Tezauraul de la Golesti. Cum a descoperit Iulian, "un roman cu spirit civic", comoara lui Murad al II-lea. Available online: http:/ / www.gandul.info/reportaj/tezaurul-de-la-golesti-cum-a-descoperit-iulian-unroman-cu-spirit-civic-comoara-lui-murad-al-ii-lea-11298952 (accessed on 5 November 2018).

22. TVR+. Available online: http:/ / www.tvrplus.ro/ / editie-telejurnal-150122 (accessed on 23 October 2018).

23. Merryman, J.H. Two Ways of Thinking About Cultural Property. Am. J. Int. Law 1986, 80, 831-853. [CrossRef]

24. Detectoristii se Revolta, Dupa ce Ministerul Culturii Analizeaza Propunerea de a Fi Scosi in Afara Legii. Available online: http:/ / adevarul.ro/locale/targu-jiu/detectoristii-revolta-ministerul-culturii-analizeazapropunerea-scosi-afara-legii-1_569e041737115986c6abeaac/index.html (accessed on 16 October 2018).

25. Vlad Alexandrescu, Ministrul Culturii, A Demisionat. Available online: https://www.mediafax.ro/politic/ vlad-alexandrescu-ministrul-culturii-a-demisionat-15275242 (accessed on 6 November 2018).

26. MINISTRII CULTURII 1862-2018. Available online: http://www.patrimoniubotosani.ro/Ministrii\% 20culturii.htm (accessed on 21 October 2018).

27. Barbatul Care A Descoperit Tezaurul de Monede de la Golesti, Premiat Cu 45,000 de Lei de Ponta. Available online: http:/ / www.mediafax.ro/cultura-media/barbatul-care-a-descoperit-tezaurul-de-monede-de-lagolesti-premiat-cu-45-000-de-lei-de-ponta-11314773 (accessed on 16 October 2018).

28. Patrimoniul Istoric National între Profesionism Si Amatorism. Available online: https:/ /www.petitieonline. com/patrimoniul_istoric_national_intre_profesionism_si_amatorism (accessed on 22 October 2018).

29. Dacian Gold Bracelets. Available online: https://traffickingculture.org/encyclopedia/case-studies/daciangold-bracelets / (accessed on 25 October 2018).

30. Tubb, K.W. Artifacts and Emotion. In Archaeology, Cultural Heritage and the Antiquities Trade; Brodie, N., Kersel, M., Luke, C., Tubb, K.W., Eds.; University Press of Florida: Gainesville, FL, U.S, 2006; ISBN 9780813037110.

31. Treasure Act 1996 Code of Practice (2nd Revision). Available online: https://www.gov.uk/government/ uploads/system/uploads/attachment_data/file/77532/TreasureAct1996CodeofPractice2ndRevision.pdf (accessed on 16 October 2018).

32. Frigo, M. An example of national implementation of EC rules. In Handbook on the Law of Cultural Heritage and International Trade. Research Handbooks on Globalisation and the Series; Nafziger, J.A.R., Paterson, R.K., Eds.; Edward Elgar: Northampton, UK, 2014.

33. Rush, L.; Millington, L.B. The Carabinieri Command for the Protection of Cultural Property: Saving the World's Heritage; Boydell \& Brewer: Woodbridge, UK, 2015.

34. Code of the Cultural and Landscape Heritage. Available online: http://www.unesco.org/culture/natlaws/ media/pdf/italy/it_cult_landscapeheritge2004_engtof.pdf (accessed on 16 October 2018).

35. Park, S.J. The cultural property regime in Italy: An industrialized source nation's difficulties in retaining and recovering its antiquities. Univ. Pennsylvania J. Intern. Law 2002, 23, 931-954. 
36. Missione TPC. Available online: http://www.carabinieri.it/cittadino/giochi/missione-tpc (accessed on 25 October 2018).

37. Portable Antiquities Scheme. Available online: https:/ / finds.org.uk/ (accessed on 7 October 2018).

38. Bors, C. Analiza asupra stadiului implementarii prevederilor conventiei de la Valleta in Romania. In Tendinte Curente in Protectia Patrimoniului Archeologic in Romania si Republica Moldova; Musteata, S., Ed.; Editura ARC: Chisinau, Romania, 2016.

39. Fincham, D. Social Norms and Illicit Cultural Heritage. In Enforcing International Cultural Heritage Law; Francioni, F., Gordley, J., Eds.; Oxford Scholarship Online: Oxford, U.S, 2013; pp. 206-227.

40. Amineddoleh, L.A. The Role of Museums in the Trade of Black Market Cultural Heritage Property. Art Antiq. Law 2013, 18, 227-254.

41. Byrne, D. Buddhist stupa and Thai social practice. World Archaeol. 1995, 27, 266-281. [CrossRef]

42. Hicks, R.D. A model investigative protocol for looting and Anti-looting education program. In Archaeology, Cultural Heritage and the Antiquities Trade; Brodie, N., Kersel, M., Luke, C., Tubb, K.W., Eds.; University Press of Florida: Gainesville, FL, USA, 2006; pp. 133-146. ISBN 9780813037110.

43. Paynton, C. The Portable Antiquities Scheme and Education. In Metal Detecting and archaeology; Thomas, S., Stone, P.G., Eds.; The Boydel Press: Woodbridge, UK, 2008; pp. 203-213.

44. Christenson, A.L. The co-production of archaeological knowledge: The essential relationship of amateurs and professionals in 20th century American archaeology. Complutum 2013, 24, 63-72.

(C) 2018 by the author. Licensee MDPI, Basel, Switzerland. This article is an open access article distributed under the terms and conditions of the Creative Commons Attribution (CC BY) license (http://creativecommons.org/licenses/by/4.0/). 